\title{
Discussion of "Characterization and Engineering Properties of Dry and Ponded Class-F Fly Ash" by R. C. Bachus, M. Terzariol, C. Pasten, S. H. Chong, S. Dai, M. S. Cha, S. Kim, J. Jang, E. Papadopoulos, S. Roshankhah, L. Lei, A. Garcia, J. Park, A. Sivaram, F. Santamarina, X. Ren, and J. C. Santamarina
}

\section{K. Prakash, Ph.D.}

Professor and Head, Dept. of Civil Engineering, Sri Jayachamarajendra College of Engineering, Mysuru 570006, India (corresponding author). Email:kprakash60@yahoo.com

\begin{abstract}
A. Sridharan, Ph.D., D.Sc.
Indian National Science Academy Honorary Senior Scientist, Indian National Science Academy, Delhi, India; formerly, Professor, Dept. of Civil Engineering, Indian Institute of Science, Bengaluru 560012, India. Email: sridharanasuri1937@gmail.com
\end{abstract}

https://doi.org/10.1061/(ASCE)GT.1943-5606.0001986

The authors must be complemented for throwing light on several properties of fly ash including the dynamic properties of Class F fly ash and its diagenetic behavior. The authors project their paper as a documentation of a comprehensive study of Class F fly ash including data compiled from the published literature. Their claim appears to be incomplete for the following reasons.

Because India is one of the countries where coal is being used as the primary source of energy, many basic and applied research works have been carried out in India during the 1990s and the first decade of the 21st century. The most important of these works is the Technology Information, Forecasting and Assessment Council (TIFAC) project, sponsored by the Department of Science and Technology, Government of India, and carried out at the Indian Institute of Science, Bengaluru and elsewhere in India. These research works pertaining to physical properties, chemical properties, compositional behavior, strength behavior, compressibility behavior, permeability behavior, and dispersive behavior of Indian coal ashes and also on fly ash storage, disposal, and utilization systems were published on various platforms (e.g., Dayal et al. 1991; Pandian et al. 1998; Sridharan et al. 1998a, b; Gandhi et al. 2000; Pandian et al. 2000; Sridharan et al. 2000; Pandian et al. 2001a, b; Sridharan et al. 2001; Prakash and Sridharan 2006a, 2009). Based primarily on the Indian coal ash research, a comprehensive reference book was also published (Sridharan and Prakash 2007). This book also throws light on issues such as segregation and layering in an ash pond, variation in specific gravity values, and coal ash stabilization. The paper under discussion does not make any mention of these published works.

Apart from this issue, the discussers wish to draw the attention of the authors to the following:

- The paper makes a mention of the liquid and plastic limits of fly ashes. Because fly ashes are not charged particles like clays, they are essentially nonplastic materials. The conventional Casagrande method and 3-mm thread rolling method can not be adopted at all to determine the liquid and plastic limits of fly ashes. The fall cone method of determining the liquid limit has its own serious limitations and the values of liquid limits obtained by the fall cone method are questionable (e.g., Prakash and Sridharan 2006a).

- Because the fly ashes are essentially nonplastic materials, the question of classifying them using the plasticity chart does not arise. Prakash and Sridharan (2006b) developed a separate classification system for coal ashes in line with the Unified Soil Classification System (Bowles 1997).

The information presented in the paper needs to be studied considering these points and publications cited.

\section{References}

Bowles, J. E. 1997. Foundation analysis and design. New Delhi, India: Tata McGraw Hill Education.

Dayal, U., R. Sinha, and V. Kumar, eds. 1991. Fly ash disposal and deposition-Beyond 2000AD. New Delhi, India: Narosa Publishing.

Gandhi, S. R., V. S. Raju, and V. Kumar, eds. 2000. Management of ash ponds. New Delhi, India: Narosa Publishing.

Pandian, N. S., K. C. Krishna, and A. Sridharan. 2001a. "California bearing ratio behaviour of soil/fly ash mixture.” J. Test. Eval. 29 (2): 220-226. https://doi.org/10.1520/JTE12249J.

Pandian, N. S., C. Rajasekhar, and A. Sridharan. 1998. "Studies of the specific gravity of some Indian coal ashes." J. Test. Eval. 26 (3): 177-186. https://doi.org/10.1520/JTE11990J.

Pandian, N. S., A. Sridharan, and G. Chittibabu. 2001b. "Shear strength of coal ashes for geotechnical applications." In Proc., Indian Geotechnical Conf., 466-469. Indore, India: Indian Geotechnical Society Indore Chapter.

Pandian, N. S., A. Sridharan, and S. Srinivas. 2000. "Angle of internal friction for pond ashes." J. Test. Eval. 28 (6): 443-454. https://doi.org/10 .1520/JTE12135J.

Prakash, K., and A. Sridharan. 2006a. "Critical appraisal of the cone penetration method of determining soil plasticity." Can. Geotech. J. 43 (8): 884-888. https://doi.org/10.1139/t06-043.

Prakash, K., and A. Sridharan. 2006b. "A geotechnical classification system for coal ashes." Proc. Inst. Civ. Eng. Geotech. Eng. 159 (2): 91-98. https://doi.org/10.1680/geng.2006.159.2.91.

Prakash, K., and A. Sridharan. 2009. "Beneficial properties of coal ashes and effective solid waste management." Pract. Period. Hazard. Toxic Radioact. Waste Manage. 13 (4): 239-248. https://doi.org/10.1061 /(ASCE)HZ.1944-8376.0000014.

Sridharan, A., N. S. Pandian, and P. S. Prasad. 2000. "Liquid limit determination of class F coal ash." J. Test. Eval. 28 (6): 455-461. https://doi .org/10.1520/JTE12136J.

Sridharan, A., N. S. Pandian, and S. Srinivas. 1998a. "Use of fly ash to improve the CBR of soils." In Proc., Indian Geotechnical 
Conf., 261-264. New Delhi, India: Indian Geotechnical Society Delhi Chapter.

Sridharan, A., N. S. Pandian, and S. Srinivas. 2001. "Compaction behaviour of Indian coal ashes." Ground Improv. 5 (1): 13-22. https://doi.org /10.1680/grim.2001.5.1.13.
Sridharan, A., N. S. Pandian, and P. Srinivasa Rao. 1998b. "Shear strength characteristics of some Indian fly ashes." Ground Improv. 2 (3): 141146. https://doi.org/10.1680/gi.1998.020304.

Sridharan, A., and K. Prakash. 2007. Geotechnical engineering characterisation of coal ashes. New Delhi, India: CBS Publishers and Distributors. 